\title{
Comparative Analysis of Change Management Models Based on an Exploratory Literature Review
}

\author{
ANARA BEKMUKHAMBETOVA* \\ *Corvinus University of Budapest, Doctoral School of Business and Management; \\ anara.bekmukhambetova@gmail.com
}

DOI: $10.14267 / 978-963-503-867-1 \_10$

\begin{abstract}
Nowadays, a lot of companies are faced with the urgency of change in their daily operations. This is especially relevant in modern business development conditions when constant changes are considered critical for a company to adapt to market requirements and the global economic situation. The paper presents the audit of the most famous change management models. Change management is an endless cycle, and it requires a sound vision, plan, time, aptitudes, inspiration, monetary and automatic endeavors to execute the change. Successful change management is a venture and contributes to a hierarchical turn of events. There are a few models of change management available and choosing the right change management model is vital for leading or guiding productive and smooth transitions. The main goal of this paper is to describe the main differences between the well-known change management models by reviewing the relevant literature. The analysis led to the conclusion that it is impossible to pick up an optimal approach to change management. Every approach to change management attracts attention to various aspects of this problem; however, they do not exclude but complement each other.
\end{abstract}

Keywords: change management, change models, organizational change.

Funding: the author did not receive any grant or institutional support in relation to the study's preparation. 


\section{Introduction}

The term 'Change Management' is explained in the literature by different authors (e.g., Moran and Brightman, Fincham, Rhodes, Anyieni, Bcom) in different ways. In common, change management is a transformation process in strategy, processes and human resources. International research by McKinsey shows that $70 \%$ of corporate transformations fail. 39\% of failures are explained by the resistance of employees to changes, $33 \%$ by the lack of support for changes from the managers, and only $14 \%$ by inadequate resources and other reasons. Thus, the corporate culture is a crucial factor in making changes (Shapenko, 2017). There are many reasons to study change management, both from a corporate or personal point of view. Change management helps to understand the environment at the micro and macro levels, supports corporate goal setting, supports corporate goal setting; and contributes to developing and implementing effective strategies assessing the impact of change on external and internal activities. Change management is also vital for the employees themselves. Change management is also vital for the employees themselves. Employees receive change management plans, hence their understanding and involvement in change is important for the organization's survival or growth. Therefore, implementing change management through training and establishing high-performance practices is critical to building robust organizations.

This paper aims to discuss the role and significance of change management models and compare popular models used by organizations to effectively manage the transition stage. The article also attempts to systematize the knowledge associated with change management and the main models related to this issue. To achieve this goal, an exploratory analysis of the literature on this topic was carried out, oriented approaches, and the models based on which effective change management is carried out. The author has studied four mostly used models adopted by organizations for change management and has compared these models: Lewin's model of change; theory E and theory O of organizational change; ADKAR model; and Kotter`s model.

The theoretical background section is based on comprehensive literature review for introduction major models; result section compare various advantages and disadvantages are identified for each model and recommendations and implications for research as well as management are introduced. 


\section{Theoretical background}

Nowadays, change is synonymous with standard business practice, and business needs to change to develop and be competitive. There is a large number of literature sources from several disciplines dealing with change management and its critical success factors. It is a complex topic with many contradictions (Anyieni, 2016). Though the term change management did not discourse much before the 1990s, another term, "organizational," had been used, yet shared almost similar meaning to change management (Farias \& Johnson, 2000).

The exact term of 'change management' was only concretized later in the 1960s and has developed since then (Cooperrider \& Sekerka, 2006). Moran and Brightman (2001) characterized change management as "the process of continually renewing an organization's direction, structure, and capabilities to serve the ever-changing needs of external and internal customers". According to Fincham and Rhodes (2006), "change management is the leadership and direction of the process of organizational transformation, especially with regard to human aspects and overcoming resistance to change." Anyieni, Bcom, and Campus (2013) further argue that change management means planning, initiating, realizing, controlling, and stabilizing change processes on both corporate and personal levels. Nickolas (2006) argues that the task of managing change includes its impact on people, and many managers find this difficult. Change may cover such diverse problems as strategic direction or personal development programmers for staff. Strategic, technological, and structural changes, as well as changes in attitudes and behaviors, are all aimed at competitiveness and viability.

Change management is important for the sustainability and growth of organizations (Lozano, 2013). The aim of the change within organizations is to progress from the existing state to a required state (Ragsdell, 2000). This range from small changes (Dawson, 1994; Doppelt, 2003a; Gill, 2003) to more fundamental ones (Dawson, 1994; Maurer, 1996; Meyerson, 2001; McGahan, 2004).To date, the theory of organizational change offers a large number of different models of change management that allow you to develop a common ideology and concept of change and are an excellent practical guide. In this paper four well-known models are discussed which are: Lewin's model of change; the theory of $\mathrm{E}$ and the theory of $\mathrm{O}$ organizational changes; ADKAR model; and Kotter's model. This section provides information on the indicated change models and is based on the extensive literature in this area. 


\section{Kurt Lewin's model of changes}

Lewin's change model is one of the first models of organizational change and can be called classical. The three-step approach by Kurt Lewin suggests that understanding change involves an awareness of the concept of stability. The factors that "push" for change and the forces aimed at maintaining stability, he called, respectively, "motivating" and "limiting" forces. If these forces are equal, the organization remains stable. Lewin suggested a way of looking at the overall process of making changes. He proposed that organizational changes have three steps:

1. "Unfreezing." The first step involves unfreezing the current state of affairs. It contains defining the current state, surfacing the driving and resisting forces, and picturing the desired end state (Cameron, Green, 2019). It is necessary to justify the need for changes and describe in detail the proposed methods of reform. This stage aims to motivate the business for a change.

2. "Moving." This step is about moving to a new state through participation and involvement. At this stage, planned actions are performed to change the behavior of employees.

3. "Freeze." The third focuses on stabilizing the new state of affairs by setting policy, rewarding success, and establishing new standards (Cameron, Green, 2019). Activities aimed at the consolidation of new organizational practices. It is necessary to convince the staff of the organization of the effectiveness of new methods, promoting the benefits of the new system.

The three-step approach to change requires investment in significant resources (Levin, 1951). Despite its apparent simplicity, it is also argued that Lewin's theory focused on the magnitude of change while ignoring the speed of change hence not applicable in radical processes (Quinn, 1980-1982). Quinn opines that it is often a question of time before incremental change results in comprehensive transformations. Of note is the fact that Lewin's change model focuses on behavioral changes from diverse angles such as group, organizational and societal change (Dickens and Watkins, 1999), but to the contrary, the applicability of rapid and transformational changes only works best in situations that demand major structural adjustments (Cummings \& Worley, 1997). The other argument established was that Lewin's theory ignored the role of politics and power as far as conflicts in organizations are to be discussed (Dawson, 1994); Hatch, 1997); Wilson, 1992). The other criticism was derived from Lewin's idea that top-down management systems worked best for change implementation, unlike the bottom-up management system (Dawson, 1994); Wilson, 1992). 


\section{Theory $E$ and $O$ of organizational change}

Every business's change initiative is unique, and s there are two archetypes, or theories, of change. These archetypes are based on very different and often unconscious assumptions by senior executives - and the consultants and academics who advise them - about why and how changes should be made. Theory $\mathrm{E}$ is change based on economic value. Theory $\mathrm{O}$ is change based on organizational capability. Both are valid models and achieves some of management's goals, either explicitly or implicitly (Nohria, Beer, 2020). Theory E and Theory $\mathrm{O}$ are not mutually exclusive. For example, reducing occupancy costs (Theory E) while increasing flexible work policies (Theory $\mathrm{O}$ ) are not at odds with each other; they are complementary strategies. The managers who follow the "E theory" apply rather hard methods, as a rule, dwelling upon changes fulfillment up and down and attaching importance to the creation of certain structure, which means that a mechanistic approach is applied. The followers of "O theory" - are mostly oriented to the staff training and development, changes of corporate culture, and the changes up and down. The characteristics of these theories are presented in Table 1.

Table 1: Theory E and O

\begin{tabular}{lll}
\hline Characteristics & $\begin{array}{l}\text { "Theory E" (authoritarian style } \\
\text { of management) }\end{array}$ & $\begin{array}{l}\text { "Theory O" } \\
\text { (democratic style of management) }\end{array}$ \\
\hline Changes Goal & $\begin{array}{l}\text { Income rise (economic goals) } \\
\text { Leadership }\end{array}$ & $\begin{array}{l}\text { Is spread according to the } \\
\text { principle up and down } \\
\text { changes }\end{array}$ \\
$\begin{array}{ll}\text { The structure and system } \\
\text { ("hard" elements) }\end{array}$ & $\begin{array}{l}\text { All links are involved } \\
\text { Organizational structure ("soft" } \\
\text { elements) }\end{array}$ \\
$\begin{array}{ll}\text { Changes Planning } \\
\text { Changes Motivation }\end{array}$ & $\begin{array}{l}\text { Programmed Planned Changes } \\
\text { The Consultants Part }\end{array}$ & $\begin{array}{l}\text { Spontaneous Changes (the reaction } \\
\text { to possibilities which occur) }\end{array}$ \\
$\begin{array}{l}\text { According to an approach to } \\
\text { technologies and decisions } \\
\text { fulfillment in the system of } \\
\text { company management }\end{array}$ & $\begin{array}{l}\text { The formation of measures for } \\
\text { organizational changes in the } \\
\text { system of management of } \\
\text { higher link of managerial staff }\end{array}$ & $\begin{array}{l}\text { The combination of different stimulus } \\
\text { Staff involvement into the decision- } \\
\text { making process }\end{array}$ \\
\hline
\end{tabular}

Source: Michael Beer and Nytin Norhia, (2000) 


\section{Awareness, Desire, Knowledge, Ability, Reinforcement (ADKAR) Model}

The ADKAR Model (Hiatt, 2013) focuses on people change adaptation, as opposed to the change itself. ADKAR is an acronym that represents the five tangible and concrete outcomes that people need to achieve for lasting change: awareness, desire, knowledge, ability and reinforcement.

Figure 1: ADKAR Model

\begin{tabular}{|c|c|c|c|c|}
\hline $\begin{array}{l}\text { Understand } \\
\text { need for change }\end{array}$ & $\begin{array}{c}\text { Support of } \\
\text { change. } \\
\text { Participate and } \\
\text { engage }\end{array}$ & $\begin{array}{l}\text { How to change } \\
\text { and what the } \\
\text { change entails }\end{array}$ & $\begin{array}{c}\text { Skills required } \\
\text { to implement } \\
\text { change }\end{array}$ & $\begin{array}{l}\text { To maintain } \\
\text { and sustain } \\
\text { change }\end{array}$ \\
\hline
\end{tabular}

Source: Haitt, J.M. and Creasey, T.J. (2013).

\section{Kotter's 8-Step Model}

Kotter's 8-step change model is a popular framework for successful organizational change implementation utilized in many industries. Kotter's change model emphasized the importance of a holistic approach to change, and the probability of successful implementation of organizational changes is only 30\%. Although employees will see progress, leaders must be prepared to face opposition from within the organization. The way forward is by formally addressing the opposition and highlighting the contradictions in the resistant idea that the new practice is intended to overcome (Hultman, 2003). However, the theory does not understand that there is no fixed parameter to legitimize a vision. It is also the duty of the leadership to estimate the vision set based on a shared understanding with the coalition team. While it focuses primarily on rolling out your changes everywhere, Kotter's model is essentially a top-down approach. The employees do not have input or the choice to share thoughts before strategic vision creation. Another drawback happens if a stage is skipped or executed erroneously, influencing different advances, and leaving the association and venture group to defer or relapse. As a result, there could be wasted time and effort (Galli, 2018). 
Figure 2: Kotter`s 8-Step Model

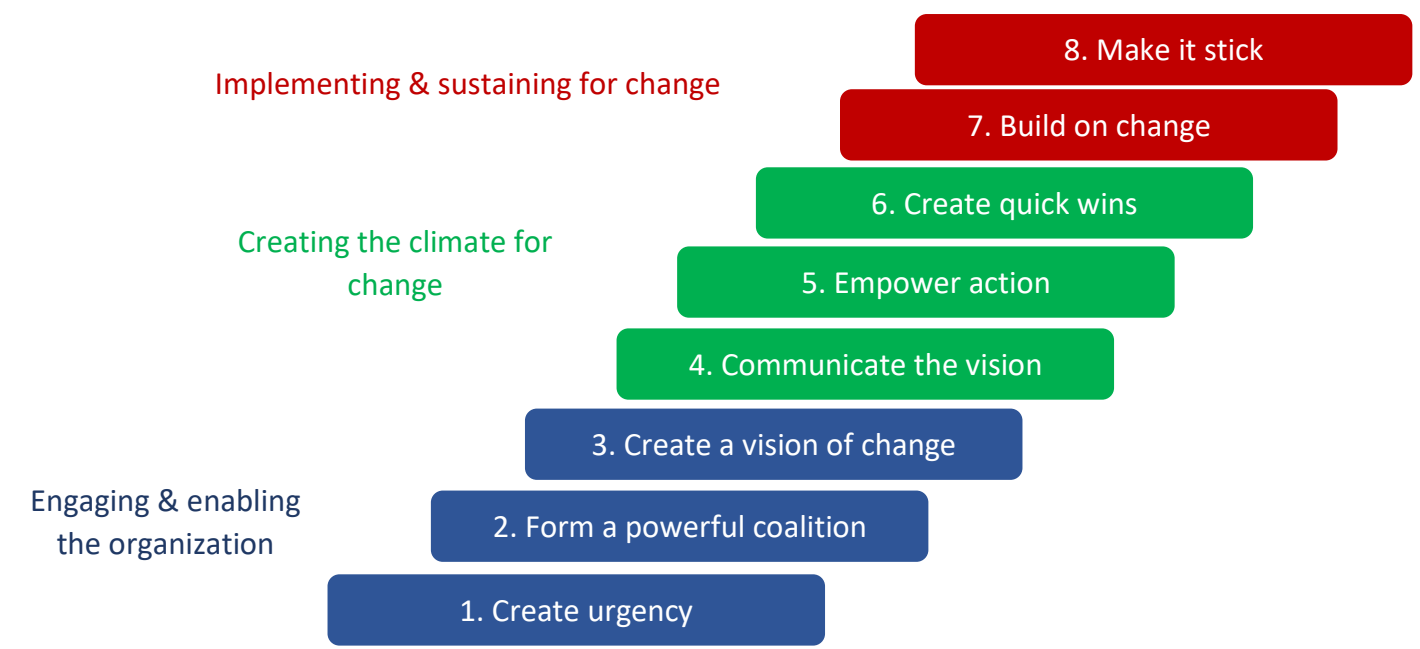

Source: Adapted from Kotter (1996)

\section{Methods}

This article uses a comprehensive literature review that explores, criticizes, and synthesizes representative material on key variables in effective change management. Essential research findings have been incorporated into the literature, and new concepts have been developed on this topic that can be empirically tested in future research. The methodological and theoretical basis of the article is scientific research by Kotter, J.P., Lewin, K. Michael Beer, and Nytin Norhia and others. Search Code: TITLE-ABS-KEY ("Change Management" OR "Change management models," AND "Approaches" OR "Business Transformation" OR "Organizational Change"). The main information base of the study was data from EconBiz, Emerald Insight, McKinsey \& Companies. Literature collection on 20/12/2020 included 57 citations, 25 articles retrieved for final screening, 3 articles excluded after full text screening, 22 articles included in analysis. In the process of writing the article, Kazakh and foreign periodicals were also analyzed. Information sources on the Internet, official websites of international organizations also served as sources of additional information. 


\section{Results}

To date, the theory of organizational change offers a large number of different models of change management that allow developing a common ideology and concept of change. The most exciting and useful are: the Lewin's model of change, the theory of E, and the theory of $\mathrm{O}$ of organizational changes; the Awareness, Desire, Knowledge, Ability, Reinforcement (ADKAR) model; and finally, Kotter's model on change management. Each model helps to understand the fundamental concept of change management, which begins with the current state and realizes the need for change, enters the transition phase, implements the change, and then moves to the desired state and bellow the author detailed comparative analysis of change management models.

Table 2: Comparison of change management models

\begin{tabular}{|c|c|c|c|c|}
\hline Point & $\begin{array}{c}\text { Lewin's change } \\
\text { management } \\
\text { model }\end{array}$ & $\begin{array}{c}\text { Theory } \mathrm{E} \text { and } \mathrm{O} \text { of } \\
\text { organizational } \\
\text { change }\end{array}$ & $\begin{array}{c}\text { Kotter's change } \\
\text { management model }\end{array}$ & $\begin{array}{l}\text { ADKAR } \\
\text { model }\end{array}$ \\
\hline 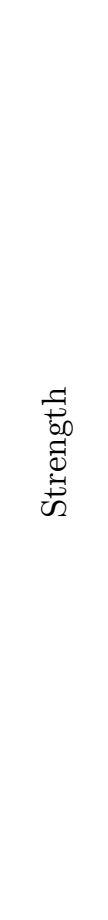 & $\begin{array}{l}\text { The model is } \\
\text { suitable for } \\
\text { cases where a } \\
\text { business needs } \\
\text { to change } \\
\text { dramatically in } \\
\text { order to be } \\
\text { successful. It } \\
\text { also does a } \\
\text { great job of } \\
\text { spotting hidden } \\
\text { bugs that were } \\
\text { taken for } \\
\text { granted as } \\
\text { there are need } \\
\text { to analyzed } \\
\text { every aspect of } \\
\text { what you are } \\
\text { changing. }\end{array}$ & $\begin{array}{l}\text { The choice of an } \\
\text { approach depends } \\
\text { on factors: the } \\
\text { nature and scale of } \\
\text { the problem facing } \\
\text { the organization; } \\
\text { the nature and } \\
\text { content of work in } \\
\text { the organization; } \\
\text { personal } \\
\text { characteristics of } \\
\text { employees; } \\
\text { leadership style and } \\
\text { the value } \\
\text { orientation of } \\
\text { management. }\end{array}$ & $\begin{array}{l}\text { The first few phases are } \\
\text { fantastic - it set the } \\
\text { stage for success by } \\
\text { creating a sense of } \\
\text { urgency and convincing } \\
\text { everyone why change is } \\
\text { needed. This gives the } \\
\text { incentive it needs to } \\
\text { implement the change, } \\
\text { and enough people are } \\
\text { working to implement it, } \\
\text { and this should quickly } \\
\text { become standard } \\
\text { practice. }\end{array}$ & $\begin{array}{l}\text { Focuses on the } \\
\text { activities for } \\
\text { achieving } \\
\text { results, model } \\
\text { is more } \\
\text { beneficial for } \\
\text { integrating the } \\
\text { management } \\
\text { concepts. }\end{array}$ \\
\hline
\end{tabular}




\begin{tabular}{|c|c|c|c|c|}
\hline Point & $\begin{array}{l}\text { Lewin's change } \\
\text { management } \\
\text { model }\end{array}$ & $\begin{array}{c}\text { Theory E and } \mathrm{O} \text { of } \\
\text { organizational } \\
\text { change }\end{array}$ & $\begin{array}{l}\text { Kotter's change } \\
\text { management model }\end{array}$ & $\begin{array}{c}\text { ADKAR } \\
\text { model }\end{array}$ \\
\hline 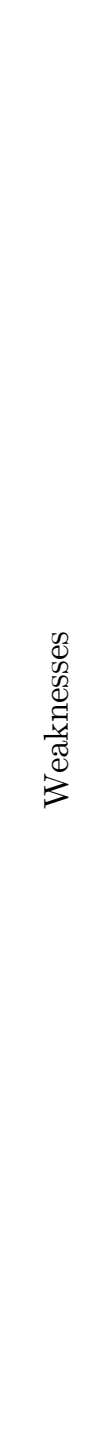 & $\begin{array}{l}\text { Due of the } \\
\text { scale of the } \\
\text { defrosting } \\
\text { process, the } \\
\text { Levin model } \\
\text { can be difficult } \\
\text { and time- } \\
\text { consuming to } \\
\text { implement, } \\
\text { meaning that } \\
\text { the use of the } \\
\text { model is often } \\
\text { only needed for } \\
\text { in-dept analysis } \\
\text { and overhaul. } \\
\text { Massive } \\
\text { changes (for } \\
\text { which this } \\
\text { model is } \\
\text { suitable) are } \\
\text { fraught with } \\
\text { the risk of } \\
\text { employee } \\
\text { churn, as their } \\
\text { workflow will } \\
\text { be radically } \\
\text { different from } \\
\text { the previous } \\
\text { one. }\end{array}$ & $\begin{array}{l}\text { The model cannot } \\
\text { be executed } \\
\text { efficiently in a short } \\
\text { time or in a short } \\
\text { period of time. You } \\
\text { will not have the } \\
\text { necessary knowledge } \\
\text { to evaluate every } \\
\text { element of your } \\
\text { company, and } \\
\text { therefore need to } \\
\text { allocate additional } \\
\text { time and resources } \\
\text { to build an } \\
\text { overview and } \\
\text { evaluate viable } \\
\text { changes. }\end{array}$ & $\begin{array}{l}\text { While it focuses } \\
\text { primarily on rolling out } \\
\text { changes everywhere, } \\
\text { Kotter's model is } \\
\text { essentially a top-down } \\
\text { approach. This is likely } \\
\text { because much of } \\
\text { Kotter's experience } \\
\text { came from working with } \\
\text { large companies, but it } \\
\text { can nevertheless be a } \\
\text { problem for companies } \\
\text { relying on more } \\
\text { collaborative } \\
\text { customization. Not } \\
\text { suitable for a small } \\
\text { company. Model the } \\
\text { most limited on the } \\
\text { people aspect. }\end{array}$ & $\begin{array}{l}\text { Model is } \\
\text { limited when } \\
\text { seeking large- } \\
\text { scale } \\
\text { implementatio } \\
\text { ns Failure to } \\
\text { effectively } \\
\text { understand } \\
\text { and manage } \\
\text { why change } \\
\text { management } \\
\text { initiatives are } \\
\text { labelled } \\
\text { nebulous and } \\
\text { trivial } \\
\text { businesses. }\end{array}$ \\
\hline 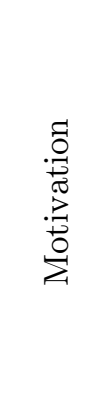 & $\begin{array}{l}\text { Must use } \\
\text { organizational } \\
\text { incentives that } \\
\text { support, not } \\
\text { lead the desire } \\
\text { for people to } \\
\text { make change } \\
\text { real. }\end{array}$ & $\begin{array}{l}\text { Must use financial } \\
\text { incentives that } \\
\text { support, not lead } \\
\text { the desire for people } \\
\text { to make change } \\
\text { real. }\end{array}$ & $\begin{array}{l}\text { Must use cultural- } \\
\text { organizational incentives } \\
\text { that support, not lead } \\
\text { the desire for people to } \\
\text { make change real. }\end{array}$ & $\begin{array}{l}\text { Provides a } \\
\text { simple, easy- } \\
\text { to-use } \\
\text { framework for } \\
\text { everyone } \\
\text { involved in } \\
\text { managing } \\
\text { change. }\end{array}$ \\
\hline
\end{tabular}




\begin{tabular}{|c|c|c|c|c|}
\hline Point & $\begin{array}{l}\text { Lewin's change } \\
\text { management } \\
\text { model }\end{array}$ & $\begin{array}{c}\text { Theory } \mathrm{E} \text { and } \mathrm{O} \text { of } \\
\text { organizational } \\
\text { change }\end{array}$ & $\begin{array}{l}\text { Kotter's change } \\
\text { management model }\end{array}$ & $\begin{array}{c}\text { ADKAR } \\
\text { model }\end{array}$ \\
\hline 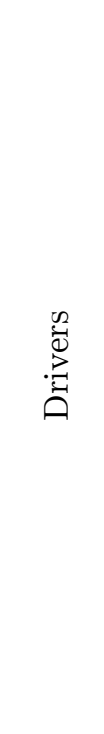 & $\begin{array}{l}\text { Lewin } \\
\text { emphasized the } \\
\text { importance of } \\
\text { preparing } \\
\text { individuals for } \\
\text { change } \\
\text { (unfreezing) } \\
\text { and reinforcing } \\
\text { the need for } \\
\text { change } \\
\text { (freezing). } \\
\text { Sponsorship } \\
\text { would certainly } \\
\text { play a part in } \\
\text { this. }\end{array}$ & $\begin{array}{l}\text { Incorporates } \\
\text { relevant change } \\
\text { agents, stakeholders } \\
\text { and team members } \\
\text { to make an effective } \\
\text { change that } \\
\text { accelerates the } \\
\text { process of change. }\end{array}$ & $\begin{array}{l}\text { The guiding coalition } \\
\text { and volunteer army are } \\
\text { important steps in } \\
\text { Kotter's process. They } \\
\text { both play crucial } \\
\text { sponsorship roles. }\end{array}$ & $\begin{array}{l}\text { Use of key } \\
\text { business } \\
\text { leaders as } \\
\text { sponsors of } \\
\text { change, and of } \\
\text { managers and } \\
\text { supervisors as } \\
\text { coaches to } \\
\text { employees } \\
\text { during the } \\
\text { change } \\
\text { process. }\end{array}$ \\
\hline 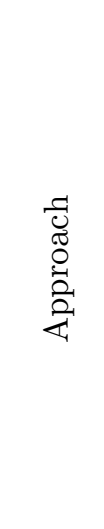 & $\begin{array}{l}\text { Involving the } \\
\text { people in the } \\
\text { process, } \\
\text { allowing them } \\
\text { time to shift, } \\
\text { and talking to } \\
\text { external } \\
\text { stakeholders } \\
\text { (e.g., employee } \\
\text { organizations) } \\
\text { if required. }\end{array}$ & $\begin{array}{l}\text { Top-down: the } \\
\text { employees do not } \\
\text { have input or the } \\
\text { option to share } \\
\text { ideas before } \\
\text { strategic vision } \\
\text { creation. }\end{array}$ & $\begin{array}{l}\text { Top-down: the } \\
\text { employees do not have } \\
\text { input or the option to } \\
\text { share ideas before } \\
\text { strategic vision creation. }\end{array}$ & $\begin{array}{l}\text { The model } \\
\text { works best } \\
\text { with } \\
\text { individuals, } \\
\text { rather than } \\
\text { groups or } \\
\text { entire } \\
\text { organizations. } \\
\text { Involving the } \\
\text { people in the } \\
\text { process. }\end{array}$ \\
\hline
\end{tabular}




\begin{tabular}{|c|c|c|c|c|}
\hline Point & $\begin{array}{l}\text { Lewin's change } \\
\text { management } \\
\text { model }\end{array}$ & $\begin{array}{c}\text { Theory } \mathrm{E} \text { and } \mathrm{O} \text { of } \\
\text { organizational } \\
\text { change }\end{array}$ & $\begin{array}{c}\text { Kotter's change } \\
\text { management model }\end{array}$ & $\begin{array}{l}\text { ADKAR } \\
\text { model }\end{array}$ \\
\hline 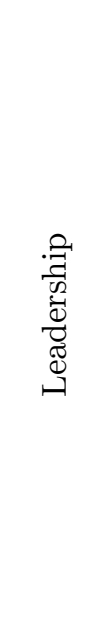 & $\begin{array}{l}\text { Defined as the } \\
\text { influence of } \\
\text { certain } \\
\text { individuals in } \\
\text { the group to } \\
\text { achieve } \\
\text { common goals. } \\
\text { A well-planned } \\
\text { change process } \\
\text { requires } \\
\text { defining a } \\
\text { vision and } \\
\text { motivation. }\end{array}$ & $\begin{array}{l}\text { Must be } \\
\text { participative top- } \\
\text { down, so that the } \\
\text { top leaders quickly } \\
\text { develop the goals } \\
\text { and encourage } \\
\text { middle layers of } \\
\text { management to } \\
\text { adopt them, and } \\
\text { middle management } \\
\text { works influence } \\
\text { upward. }\end{array}$ & $\begin{array}{l}\text { Need a strong leadership } \\
\text { culture. The leaders } \\
\text { need to develop a well- } \\
\text { designed plan. }\end{array}$ & $\begin{array}{l}\text { Allows leaders } \\
\text { and teams to } \\
\text { focus their } \\
\text { activities on } \\
\text { what will drive } \\
\text { individual } \\
\text { change and } \\
\text { therefore } \\
\text { achieve } \\
\text { organizational } \\
\text { results. }\end{array}$ \\
\hline 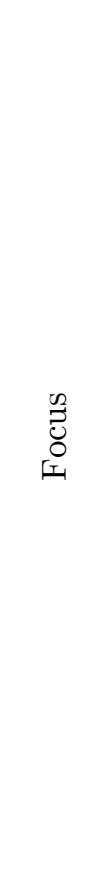 & $\begin{array}{l}\text { Given the } \\
\text { absent of } \\
\text { technology, } \\
\text { changes per se } \\
\text { were static. } \\
\text { The results of } \\
\text { change could } \\
\text { thus be } \\
\text { predicted; the } \\
\text { methods to } \\
\text { manage change } \\
\text { do not vary, } \\
\text { and hence } \\
\text { planning has a } \\
\text { critical role in } \\
\text { the } \\
\text { management of } \\
\text { change. }\end{array}$ & $\begin{array}{l}\text { A combination of } \\
\text { planned/programma } \\
\text { tic change with } \\
\text { opportunistic } \\
\text { capture of emergent } \\
\text { practices. }\end{array}$ & $\begin{array}{l}\text { The need to create short } \\
\text { wins can actually } \\
\text { increase the sense of } \\
\text { true urgency and } \\
\text { actually accomplishing } \\
\text { these goals does much to } \\
\text { cement the change } \\
\text { initiative. }\end{array}$ & $\begin{array}{l}\text { Most effective } \\
\text { when } \\
\text { managing staff } \\
\text { in helping } \\
\text { them see and } \\
\text { accept the } \\
\text { value of } \\
\text { change and } \\
\text { their role } \\
\text { within the } \\
\text { organization in } \\
\text { helping to } \\
\text { make that } \\
\text { change } \\
\text { happen. }\end{array}$ \\
\hline
\end{tabular}

Source: Completed by the author on the basis of sources considered.by Kotter (1996), Haitt and Creasey (2013), Michael Beer and Nytin Norhia (2000), Cameron, Green (2019). 
Lewin's model has had a significant impact on the further development of the theory of organizational change. Lewin's model requires in-depth analysis and process improvements. By uncovering the roots of your methods and completely changing processes and practices where necessary can change an organization at a critical time in its life cycle. Lewin's ideas are valuable when analyzing the change process at the start of an initiative. His forcefield analysis and current state/end state discussions are extremely useful tools. However, the model loses its worth when it is confused with the mechanistic approach, and the three steps become: 'plan, implement, and review.' Theory E and Theory $\mathrm{O}$ are two polar approaches to organizational change, representing two different strategies for the process of change. Theory $\mathrm{E}$ and $\mathrm{O}$ of organizational change's model is suited for those who want to know how they can change for the better. Having created an overview of how consistent and effective various elements of the company are, there are needed leaders and good employee support. Then proceed to analyze the current situation and develop changes to solve the problem model that combines a number of key elements management model of organizational change together in a neat process. The ADKAR model is founded on three phases and it deals with the process and steps to manage change. It is a goal-oriented model and focuses on the activities for achieving results. The ADKAR model is more beneficial for integrating the management concepts in the change management process (Siddiqui, 2017). Kotter's theory is great as a checklist but lacks the necessary actionable instructions to be taken as a step-by-step process. Kotter's model should be supplemented with other approaches or at least their elements to make up for its shortcomings. The model places most emphasis on getting the early steps right: building a coalition and setting the vision rather than later stages of empowerment and consolidation. Change is seen as linear rather than cyclical, which implies that a pre-designed aim.

\section{Discussion and recommendations}

According to the reviewed material, it should be noted that there is no one ideal specific version of change management. The choice of an approach should be based on consideration of real conditions, as well as on the integration of several models. In an attempt to compare popular change management models from theoretical viewpoint were considered and the study is open to future research and a deeper understanding of the changes and will help future researchers with suggestions.

The study suggests that for future research, sufficient time should be allocated for more in-depth analysis, and the practical component should be considered. This is beneficial to the extent that it allows the researcher to find many companies that will be included in the data collection process. This will provide a real picture of the theories from the practice 
side in real organizations. The empirical validation of will allow to investigate the efficiency of change management models implementation at a company depending on management style (authoritative or democratic), and to investigate the practical value of received results. Limitations of paper are determined by results based on secondary data and making assumptions based on some old data. Therefore, future researchers are encouraged to constructively criticize, propose alternatives and solve academic problems, and most importantly-to be flexible and adaptive to new concepts of change management.

\section{References}

Abel Anyieni (2016), Organisational Change: A Critical Review of the Literature, https://www.semanticscholar.org/paper/Organisational-Change\%3A-A-Critical-Reviewof-the-Anyieni/168d486f3a71fd19bd9a92e8623e808728ddd9ce

Dawson, P. (1994). Organizational change: A processual approach. London: Paul Chapman.

Esther Cameron \& Mike Green (2009). Making sense of change management, Lndon and Philadelphia 2nd edition.

Fincham, R. and Rhodes P. (2005).Principals of Organisational Behaviour. Oxford University Press

Galli B.J. (2018). Change Management Models: A Comparative Analysis and Concerns IEEE Engineering management review. 46, NO. 3.

Haitt, J.M and Creasey, T.J.(2013). Change Management: the people side of change. Colorado: Prosci Learning Center Publication

Kotter, J. P. (1996). Leading change. Cambridge, MA, USA: Harvard Business School Press.

Lewin, K. (2016). Available: http://change-management-consultant.com/kurtlewin.html.

Lozano, R. (2013). Corporate Social Responsibility and Environmental Management. Are companies planning their organisational changes for corporate sustainability? An analysis of three case studies on resistance to change and their strategies to overcome it, 20(5), 275-295.

Moran, J. W., \& Brightman, B. K. (2001). Career Development International,6(2). Leading organizational change, pp. $111-118$.

Nitin Nohria and and Michael Beer (2000). Business Harvard review. Cracking the Code of Change, https://hbr.org/2000/05/cracking-the-code-of-change.

Saima Tabassum Siddiqui (2017). International Journal of Advanced Research. A critical review of change management strategic and models, 5(4), 670-676

Shapenko A, Filippova M. (2010) Business Harvard review. The burden of change. 